\title{
THE DILEMMA BETWEEN RELIGIOUS DOCTRINE AND POLITICAL PRAGMATISM: STUDY OF HAMAS IN PALESTINE
}

\author{
Mulawarman Hannase \\ Department of Middle East and Islamic Studies \\ Universitas Indonesia \\ Email: mulawarmanhannase@ui.ac.id
}

\begin{abstract}
This paper aims to examine how Hamas as an Islamic movement which adheres to the Muslim Brotherhood ideology came into the political public sphere from 2006 until today. Can Hamas maintain the purity of its religious doctrine when the movement engages in a political election in Palestine? This research uses a qualitative method and adopts the theory of political normalization by Antony Bubalo and Greg Feely to analyze how Islamists movement runs into a secular democratic system by participating in the election, establishing political parties, and contributing within a parliamentary and presidential system. From a theological perspective, this research shows that violence involved by an Islamist group in particular due to their theological interpretation. Meanwhile, from a political perspective, Hamas tries to adapt its approach with the political condition and runs with the contextual realm as well as other political groups from different ideological backgrounds.
\end{abstract}

[Tulisan ini menjelaskan bagaimana Hamas, yang memiliki haluan ideologis sejalan dengan kelompok Ikhwanul Muslimin, masuk dalam ranah politik mulai dari 2006 hingga sekarang. Dapatkah Hamas memelihara keaslian dokrin yang dianut ketika memasuki kontestasi politik 
elektoral di Palestina? Kajian ini menggunakan metode kualitatif dengan mengadopsi teori 'normalisasi politik' Antony Bubalo dan Greg Feely untuk menganalisis kelompok Islamis ketika melakoni praktik politik dalam sistem demokrasi sekuler, seperti terlibat dalam pemilu, mendirikan partai politik, dan bergabung dalam pemerintahan yang menganut sistem presidensil dan parlementer. Studi ini menunjukkan bahwa dari perspektif ideologis, konflik kekerasan yang melibatkan kelompok Islamis disebabkan karena kuatnya doktrin teologis yang dianut melalui interpretasi keagamaannya. Sedangkan dari perspektif politik, gerakan Islamis tidak konsisten dengan flatform ideologis yang dianut, dimana perilaku politiknya mencoba untuk diadaptasikan dengan kondisi politik yang terjadi, serta berperilaku sama dengan partai politik lainnya dari berbagai macam latar belakang ideologis.]

Keywords: Palestine, Hamas, Islamist movement, political pragmatism.

\section{Introduction}

Some experts argue that religion is a source of conflict or at least gives legitimacy to various social conflicts. Others conclude that religion does not contain the teachings and commands that legitimize violence, because religion contains the values of peace. ${ }^{1}$ According to Armstrong religious fundamentalism led to the emergence of a radical movement, potentially in every divine religion including Judaism, Christianity, and Islam. ${ }^{2}$ Meanwhile, according to Khaled Abou al-Fadl, no religion exactly teaches conflict and violence. ${ }^{3}$

\footnotetext{
1 Read in Tariq Ali, The Clash of Fundamentalism; Crusades, Jihad, and Modernity (London: Verso, 2003).

${ }^{2}$ Karen Armstrong, The Battle for God; Fundamentalism in Judaism, Christianity, and Islam (London: Harper Collins Publisher, 2003). 1-5.

${ }^{3}$ Khaled Abou El Fadl, "Peaceful Jihad," in the Michael Wolfe (ed.) Taking Back Islam: American Muslims Reclaim Their Faith, (USA: Royale, 2004), 38.
} 
Hamas, ${ }^{4}$ as an "Islamic Resistance Movement" in Palestine, constructed its ideology based on Islamic teaching. The majority of Western society perceived Hamas as an Islamist-extremist ${ }^{5}$ because it had been involved in various conflicts. According to Azzam Tamimi, the ideology of Islamism ${ }^{6}$ embraced by Hamas movement build understanding to "return to Islam" in a holistic way.

Matthew Levitt sees Hamas as an organization that was very influential in Palestine but its ideological construction was slightly known by the public. Levitt ensures that the roots of Hamas movement came from the Muslim Brotherhood in Egypt. Besides, the factor that makes Hamas plays an important role in Palestine politics is a common resistance against Israel. Hamas gives great social contributions for the Palestinian, such as initiation to build schools, clinics, and hospitals, to help Palestinians. Therefore, Hamas is known as the movement engaged in the social issues of Palestine. ${ }^{8}$

Although Hamas has a special role in assisting the social life of Palestine and was praised for doing open resistance against Israeli occupation, the movement is often criticized for being too rigid in

\footnotetext{
حركة المقاومة الإسلامية in the Arabic language is the acronym of (Islamic Ressistent Movement). Hamas is the Islamic movement who struggled for Palestine independence from Israel's colonialization in late 1987. See Khalid Khalil Mahmud Zuaib, al-'Alāqah Baina Harakah al-Muqāwamah al-Islāmiyyah (Hamas) wa al-Urdun (Amman: Jami’ah Khalil, 2010), 2.

${ }^{5}$ Matthew Levitt labeled Hamas as a terrorist group in his work, Hamas: Politics, Charity, and Terrorism in The Service of Jihad (London: Yale University Press, 2006).

${ }^{6}$ The term "Islamism" could be found in some pieces of literature. Islamism is a revivalist fundamentalist movement that aims to reconstruct conservative Islamic understanding and concern to establish an Islamic state to implement Islamic tradition in the Muslim's life. Read Jeffrey M. Bale, "Islamism and Totalitarianism," Journal of Totalitarian Movements and Political Religions, Vol. 10 No. 2 (Juni, 2009): 73-96.

7 Azzam Tamimi, Hamas Unwritten Chapter (London: C Hurst \& Co Publisher, 2006).

${ }^{8}$ Matthew Levitt, Hamas: Politics, Charity, and Terrorism, 3.
} 
dealing with Palestinian peace project. ${ }^{9}$ Hamas said that the only way to deal with the Palestinian crisis is an armed jihad whereas other factions, namely Fatah, said that peaceful political solution is more effective in resolving the conflict. This is what makes the Palestinian problem becomes complicated, especially when Hamas decided to pursue a democratic system on the one hand, and refuses a peaceful political solution on the other.

These research attempts to look at a tiny development of Islamist groups today. The ideology of Islamism is very strong and it is supported by a textual understanding of, to name it, Islamic tradition. Such a phenomenon could be seen in the case of Hamas movement. Moreover, ideology is one of the instruments that provoke Hamas to be involved in many conflicts. This study is necessary to elucidate several forms of extremism which exist in the Islamist group.

\section{The relation between Islamism and Politics}

How did an Islamist movement emerge, adapt political realities, and participate in political practices? This question needs to be explored to look at the connection between Islamism and the political world. As Sheri Berman argued, the emergence of the Islamist movement could be associated with political problems in the Islamic world and its various localities. Among other things, there is dissatisfaction with the existing regime or the minimum level of community welfare which has triggered the spreading of political conflict. ${ }^{10}$

Islamist groups in democratic countries are usually involved in existing political contestations. This model is called the "political normalization" theory which has several slogans including "from sharia countries to sharia values." An ambiguity experienced by

\footnotetext{
${ }^{9}$ Hamas rejected a peaceful political solution as expressed by its leader. See, Mulawarman Hannase, Islamisme dan Konflik: Perspektif Teologis dan Politis Pemikiran dan Pergerakan Hamas (Jakarta: Bolabatu Jaya \& PSATT, 2015), 7.

${ }^{10}$ Sheri Berman, "Islamism, Revolution and Civil Society," Journal of American Political Science Association, Vol. 1 No. 2, (Juny 2003): 266.
} 
Islamist groups is its consistency in maintaining the purity of doctrine and the demand to adapt political interest. This could be seen in the Muslim Brotherhood's strategy, as Sami Zemmi said, that after gaining power, the Muslim Brotherhood did not hold its mission (da'wab) program and did not consider itself as the only representation of Muslims, but a representation of the nation. Islam as teaching requires strong institutions to implement these practices in what so-called Islamic state.

Therefore, sharia is the goal and the basic ideal of the Islamists to establish an Islamic state. Although the Islamists experienced different strategies, from sharia as a goal to sharia as a set of values or principles, they must reach the goal through democratic participation. Political strategy to achieve a political or ideological goal through the system of democracy and electoral politics has been considered more effective than revolutionary movement. Islamists group, as in the case of the Muslim Brotherhood in Egypt, calculated what can be gained from their participation in the democratic system. ${ }^{11}$ However, the decision has logical consequences, namely that Islamism appears to be separately away from its historical aims and traditional thinking of the actualization of the Islamic state.

One of the important things to explain the relationship between Islamism and politics is the transformative idea from "Islamic governance" to "good governance" or secularization among the Islamist groups. It is known that al-Islam buwa al-hall is a slogan built by Islamists in Egypt to convey that Islam is the only solution for all problems of the nation. Islamists argue that the Islamic concept of leadership and state is the best answer. But in reality, the Islamists, such as the Brotherhood in Egypt, have difficulties to strategies and goals of Political Islam. As a consequence of this holistic understanding, Islamists involved in

\footnotetext{
11 Tamara Cofman Wittes, et. Al., "Islamic Parties and Democracy," Journal of Democracy, Vol. 19 (July 2008): 14.
} 
conflicts of interest with secular groups who denied formalization of Islamic law. ${ }^{12}$

The Islamists can hardly explain what so-called Islamic solution for the economic and social problems within Muslim society. The rhetoric developed by Islamists to raise the electoral level was widely adopted from non-Islamist rhetoric or secular concepts. For example, in the economic program offered by the Ikhwan-based party in Egypt in 2007, it cannot be distinguished from the economic policies adopted by the ruling party the NDP (National Democratic Party) ${ }^{13}$

That is the phenomenon of the Islamists in various countries where they are in a process of adjusting ideas to democratic principles to get support from the public. Because of political interests, they move towards secular rhetoric. The same thing also happened with PKS in Indonesia which does not consciously marginalize the issue of sharia and the Islamic state within its political participation. To get broader support from various religious and ethnic groups, not just from Islamic groups, the Islamists use the slogan of good governance such as good governance, anti-corruption, social equality and rule of law. This shows how often Islamists use secular rhetoric. ${ }^{14}$

\section{Ideological Perspective of Hamas Islamist Movement}

To deal with the ideological construction and religious doctrines embraced by Hamas, as well as to assess whether this group fundamentalist or not, there are at least three types of thought espoused by the group that is important to be investigated and

\footnotetext{
12 Abdulkader H. Sinno and Ahmad Khanani "Opportunities and Organization: When do Islamist Parties Choose to Compete Electorally" in M. A. Mohamed Salih, Interpreting Islamic Political Parties (New York: Palgrave Macmillan, 2009), 2930.

13 Anthony Bubalo, Greg Fealy, and Whit Mason, Zealous Democrats: Islamism and Democracy in Egypt, Indonesia, and Tukey (Sidney: ANU Press, 2008), 104.

14 Ibid.
} 
explored. The three kinds of thinking were: his view of the Islamic state, the doctrine of antisemitism and the sanctity of Palestine.

There are three points in the Hamas charter which became the main element of the doctrine of thought Hamas. Firstly, the quotation of verses of the Koran QS: 31:10 which invites Muslims back to the Islamic faith and the superiority of Islam over Judaism and Christianity. Secondly, a quote from the statement of Hasan alBanna saying that Israel will continue to stand before the Muslims destroy it as they destroy the Muslims of Palestine before. Therefore, the emergence of this statement in the Hamas Charter should be equating Hamas doctrine with the Brotherhood's understanding. One of the fundamental things that Hamas wants of this doctrine is to eliminate Israel is a precondition for establishing an Islamic state that was adopted from the ideology of the Brotherhood. Thirdly, excerpts of Amjad al-Zahawee, the leader of the Muslim Brotherhood in Iraq, who said that every Muslim in the Islamic world must participate in the struggle to achieve the establishment of an Islamic state in Palestine. These three points indicate the strong view of Hamas to Islamic doctrine and the Palestinian issue. ${ }^{15}$

Meanwhile, the Brotherhood ideology held by Hamas cannot be separated from the ideology of Sayyid Qutb, the Muslim Brotherhood ideologue hanged by Egyptian President Nasser in 1966, is also a major influence for all jihadist groups, the Islamic State being no exception. Qutb's contribution to jihadism was to take the idea of jabiliyyah, the concept that Arabs were in a state of ignorance before the appearance of Mohammad and his Islamic teachings, and turn it into a concept of political philosophy. Qutb termed anything other than strict adherence to sharia law and Islam jabiliyyah, including all contemporary Muslim regimes. He then advocated the violent overthrow of all such regimes to replace them with an Islamic state. In developing this concept, Sayyid Qutb built

\footnotetext{
${ }^{15}$ Muhammad Maqdsi, "Charter of the Islamic Resistance Movement (Hamas) of Palestine," Journal of Palestine Studies, Vol. 22, No. 4 (Summer, 1993): 122-134.
} 
on the earlier work of Ibn Taymiyya and the early 20th century Indian Islamist Abu Ala Maududi. These ideas were further developed by the thinkers and jihadists that would go on to form Al-Qaeda: Abdullah Azzam (the father of global jihadism) and Osama bin Laden. ${ }^{16}$

In line with the above view, Azzam Tamimi saw that Hamas religious doctrine reflects the ideas of Islamic ideological leaders such as Hassan al-Banna, Sayyid Qutb and Abdullah Azzam. These three figures are the central ideological-leaders that affect al-Qaeda and construct the doctrine of jihad, Islamic militancy and the war against the West. The second paragraph of the Charter is an excerpt from the statement of Hasan al-Banna, "Israel will exist and will continue to exist until Islam will obliterate it, just as it obliterated others before it." 17

According to Emmanuel Sivan, antisemitism in the context of Hamas understanding about Palestine was constructed by making Jews as a target-acting in radicalism, because they found that Jews manipulate the Western view of Islam and conspiring to perpetuate its existence. ${ }^{18}$ This is the core of the antisemitism concept evolving in Islam today, both in the Middle East and in other Islamic regions. It also could be identified that the Antisemitism concept was encouraging conflict between the Islamic and Jewish communities whether in the form of political conflict and violent conflict.

Based on the construction of Hamas ideology, it could be justified that this movement is a fundamentalist group heavily involved in the conflict. The religious doctrine of Hamas was adopted from the previous figures of political Islam. ${ }^{19}$ In addition, Hamas also seeks to respond to the social and political problems

\footnotetext{
${ }^{16}$ See the influence of Qutb to the Jihadis Groups in Adnan A. Musallam, From Secularism to Jibad: Sayyid Qutb and the Foundations of Radical Islamism (London: Praeger, 2005).

17 Azzam Tamimi, Hamas: Unwritten Chapter, 76.

${ }^{18}$ Emmanuel Sivan, Radical Islam, Medieval Theology and Modern Politic (New Haven: Yale University Press, 1985), 51-67.

${ }^{19}$ Osama Abu Rashid and Paul Syam, "Hamas: Tashaddud 'Aqa'idi wa Murūnah Siyāsiyyah,” Silsilah Tarjamat al-Zaitunah, Vol. 47, (Januari 2010): 4.
} 
faced since the outbreak of the first intifada. In many ways, Hamas provides a clear attitude and stance on how to deal with Israel, how its role in the Palestinian political arena and how to contribute to the Palestinians in the field of education, economics, and religion. All doctrines are built and implemented in the concept of jihad obligations..$^{20}$ Nusse, Gunning, and Tamimi assume that Hamas is a fundamentalist Islamic movement involved in the Palestinian conflict due to the influence of religious doctrine which very strong.

\section{Hamas Political Approach}

In the next period, the doctrine of Hamas is somewhat different from the Islamic thought adopted before. Hamas has originally a rigid doctrine, but in 2006 it submitted and participated in the Palestinian election. The view of Hamas seems to be more political and not lead to ideological issues. ${ }^{21}$ Hamas wants to show its ability in contributing to society by political correctness as an alternative to leadership crowded by the government. Hamas has commonly raised issues of civil society, political participation and used modern democracy terminology. As if, Hamas putting religious issues behind the political and social issues of democracy. Some researchers named Hamas as a pragmatic group. ${ }^{22}$

Looking at the strategy of the Hamas movement, there are two phases of the development of this group. The first phase is ideological began from the early days of its appearance until 2006. At this stage, Hamas adheres to religious doctrines inherited from its leaders and involved in humanitarian activities in Gaza Strip.

\footnotetext{
20 The resistant ideology constructed by Hamas is a form of jihad doctrine understood by this group. The doctrine of jihad is understood by the Islamist groups in the modern age is more likely to be physical and military, thereby this understanding has been resulting in conflict. See Mulawarman Hannase, Islamisme dan Konflik, 185.

${ }^{21}$ See Khaled Hroub, "Palestinian Islamism: Conflating Nasional Liberation and Socio-Political Change," Italian Journal of International Affairs, Vol. 43, Issue 4, (December 2008), 59-72.

22 Jeroen Gunning, Hamas in Politic: Democracy, Religion, and Violence (New York: Columbia University Press, 2009), 50.
} 
During this period, Hamas avoided political channels. Hamas rejected forms of political project to solve Palestinian issues, especially political projects that benefit the Israelis, both in the temporary or long-term interests. For Hamas, to unite Palestinians is a primary step to undertake the struggle with jihad mechanism to liberate the land of Palestine as a whole. Hamas rejected a way of dialogue with Israel to avoid recognition of the existence of the State of Israel. ${ }^{23}$ In addressing Palestinian politics, Hamas also refused to engage in practical politics because it did not provide much benefit to the liberation of Palestine.

The second phase was from 2006 until today when Hamas transformed into the path of practical politics, namely after the election win. Hamas decided to participate in the election of 2006. It shows changes in various aspects of Hamas, particularly in its political life. In such participation, Hamas won the election by winning 74 of 132 seats, while Fatah only gained 45 seats. ${ }^{24}$

The change of Political Hamas, that drove the organization to become a winner in the Palestinian political contestation at the time, attracted the attention of the international community. The United States considers Hamas victory in the Palestinian election as an accident and would hamper the peace process with Israel. ${ }^{25}$ This victory also gives a large effect on foreign aid to Hamas movement, especially from western countries: they do not want the Islamists movement to have a major influence on international policy. ${ }^{26}$

Besides rejection and criticism from outside, especially the allied countries of Israel, Hamas had to struggle with the internal

\footnotetext{
${ }^{23}$ Khaled Hroub, Hamas, al-Fikr wa al-Mumārasah (Beirut: Muassasah al-Dirāsat al-Filistīniyah, 1999), 163.

${ }^{24}$ Mariam Itani, Sirä' al-Sultat baina Fatah wa Hamas fi Idārat al-Sultah al-Filistiniyyah (Beirut: Markaz al-Zaitunah li al-Dirasat wa al-Istisharat, 2008), 7-8.

${ }^{25}$ David Makovsky, "Israeli Policy and Politics in the Wake of Hamas's Victory", in Robert Satloff (ed.), Hamas Triumphant: Implications for Security, Politics, Economy, and Strategy (Washington: the Washington Institute for Near East Policy, 2006), 17-18.

${ }^{26}$ Jim Zanotti et.al, "Israel and Hamas: Conflict in Gaza (2008-2009)" in Nejc Kardelj (ed.), Israel Versus Hamas (UK: Nova Science Publication, 2010), 79.
} 
political constellation. As Mariam Itani said, the most complex problems facing the Palestinians in 2006 are not how to win the election but how to deal with post-election conflict. ${ }^{27}$ The conflict feared was happening, where factions who feel they have the authority to represent the Palestinian people, both in the local and international sphere, have to compete with groups that are often labeled as radical and even terrorist groups, such as Hamas. Although the actual socio-political factors provided benefits for Hamas, support for Fatah is decreased caused by the inability to deliver good governance to the Palestinians. ${ }^{28}$

To build a government institution, Hamas need extensive support from the public. Accordingly, Hamas uses the slogan of "alIsläh wa al-tagyin" and requires for reformation and changes. For Hamas, waiting for building a state became politically worse, while a revolution is not a better choice. The best solution for Palestinians is to stop government corruption through the mechanism of elections, by making freedom of speech for the people. That was Hamas political reform agenda which is important to do it because, to gain political support from Palestinian people. ${ }^{29}$

Another important strategy used by Hamas is to develop a military wing to encounter the Israel army. For Hamas, military approach and jihad is the most effective choice. However, it made Gaza Strip experienced a very long-crisis. In the last decade, there have been so many times of war between Hamas and Israel. In 2004, a series of war between Israel and Hamas have rejoiced the territory. In that operation, between 104 and 133 Palestinians were killed and 5 people in the Israeli side. ${ }^{30}$

In 2014, a war between Israel and Hamas have been intensely escalated. On July 17, 2014, Israeli troops entered the Gaza

\footnotetext{
${ }^{27}$ Mariam Itani, Șirä' al-Sultat baina Fatah wa Hamas, 9.

${ }^{28}$ Jamil Hilal, al-Tanżimàt wa al-Ahräb al-Siyäsiyyah al-Filistiniyyah baina Mahām alDimuqrätiyyah al-Däkhiliyyah wa al-Dimuqrätiyyah al-Siyāsiyyah wa al-Taharrur (Ramallah: Muwatin, 2006), 52.

${ }^{29}$ Mulawarman Hannase, Islamisme dan Konflike, 112.

30 http://studies.aljazeera.net/reports/2014/07/201471711111892808.htm.
} 
Strip. More than 2100 Palestinians were killed. The war ended after a 50-day conflict when a ceasefire was agreed on August 26, 2014. At each end of the war, Hamas has always felt and celebrated victory despite the casualties of Gaza far more than that of the Israelis. ${ }^{31}$ If observed, Hamas military strategy is more likely to be directed to the resistance against Israel as a form of patriotism to defend his country.

Based on the steps mentioned above, some researchers and thinkers see that the approach of Hamas in building a peaceful way is deliberately contrary to its strategy, as stated in the Charter of Hamas. After it decides to participate in the last election and win, there arises a question on how Hamas synchronize between an opposite movement and political effort of peace through diplomacy and dialogue. It also pushed Hamas to be consistent in conducting military resistance movement against Israel.

Because it failed to harmonize the policies pursued, Hamas has been eventually trapped in the internal conflict. As two political mainstreams in Palestine, Fatah and Hamas are always conflictual in determining an appropriate model that should be implemented within the Palestinian government. Fatah, representing secular mainstream, clearly rejects the Islamists group such as Hamas because it was adopted from the idea of Hasan al-Banna and Sayyid Qutb. Fatah convinced that Hamas unlikely to accept the democratic system. However, Hamas proves that this group accepted democracy as a system by participating in the elections $2006 .{ }^{32}$

Having a different approach toward political issues in Palestine, Hamas and Fatah have been confined within a longlasting internal conflict. According to Fisher, conflict occurs due to polarization happening in a society that drives mistrust and hostility. After the emergence of Hamas, as an influential group in Palestine,

\footnotetext{
${ }^{31}$ http://www.aljazeera.net/news/reportsandinterviews/2014/7/20.

32 Mahjoob Zweiri, “The Hamas Victory: Shifting Sands or Major Earthquake?” Third World Quarterly, Vol. 27, No. 4 (2006), 678.
} 
polarization continues among Palestinian people and generates a disharmonious relationship between the authority (Fatah) and Islamist group (Hamas). ${ }^{33}$

Although there are various opinions within Hamas, the movement remained consistent to get their goal and change the status quo. Referring to its Change and Reform List Political Platform, Hamas attempt to confirm justice, fight corruption, and create an appropriate space to attain independence, freedom, and selfdetermination. One of its campaign slogans is: "America and Israel say no to Hamas. What do you say?" Hamas program has developed social integration, called for reactivation of zakat committee, and strengthened social protection. Hamas determined what the important issues to Palestinians are, among them: good governance, anti-corruption, political reformation, and good services. ${ }^{34}$

The ability of Hamas to persuade a significant number of swing voters suggests that political party identification is no longer accurate to measure political support. There is also anecdotal evidence to suggest that Hamas' message of change resonated with traditional supporters of Fatah who were disappointed with Fatah's failures. Not only did Hamas have a clear and unified message among its candidates, but it was also able to convey that message to Palestinian voters. The movement used its media outlets such as the newspaper al-Risala, Voice of Al-Aqsa Radio, and its Al-Aqsa Television station launched before the elections to broadcast its message. The television station broadcast twelve hours a day and focused mainly on the election, including campaign messages and Hamas Movement's video clips glorifying suicide bombers and Palestinian martyrs. Hamas also reportedly used SMS messaging and e-mails as election tactics. A great deal of emphasis within the campaign focused not only on the message but on the election its

\footnotetext{
${ }^{33}$ Simon Fisher (ed.), Working With Conflict: Skills and Strategies for Action (London: Zed Books, 2000).

34 Jon B. Alterman and Karin von Hippel, Understanding Islamic Charities (Washington: Center for Strategic and International Studies, 2007), 98-126.
} 
self. Here are two main areas were covered by Hamas: first dealt with the logistics and mechanics of the voting system and the second stressed compatibility of the elections with Islam and Islamic legal principles, which was a major concern for Hamas. ${ }^{35}$

In essence, Hamas no longer shows its self as an Islamist group that provides a rigid view of the Islamic-state concept. It tried to conceal a political agenda to establish an Islamic state and try to campaign himself in the democratic area like other secular parties in the word.

\section{Conclusion}

In the context of politics or say the struggle between fundamentalists and secularists in Palestine, Hamas Islamists group also uses a secular democratic system such as participating in the election, establishing a political party, and involving within a parliamentary and presidential system. Although Islamist's political view is very ideological, they have also taken part within a secular system of politics and democracy. Hamas' participation in politics eventually made such local contestation between Hamas and Fatah: the former could not accept political leadership of the latter which is relatively perceived as a secular group.

From a theological perspective, Hamas Islamist group supposed and interacted with other (political) groups based on theological arguments such as the doctrine of antisemitism, the doctrine Palestinian Land, and the doctrine of Jibad. Hamas considered that the most effective efforts to maintain freedom and independence is an armed-jihad, although the meaning of jihad is spacious. Armed Jihad (al-jihäd al-musallah) movement represented Hamas' thinking, strategy, and activity, especially at the beginning of its period. Hamas ideally tried to approve Islamic State based on the application of Sharia law and Islamic constitution, but practically it has also entangled within a secular democratic system. This

35 Ibid., 102. 
condition drives Hamas to have a dilemma between religious doctrine and political pragmatism.

\section{Bibliography}

Ali, Tariq. The Clash of Fundamentalism; Crusades, Jihad, and Modernity. London: Verso, 2003.

Alterman, Jon B., and Hippel, Karin von. Understanding Islamic Charities. Washington: Center for Strategic and International Studies, 2007.

Armstrong, Karen. The Battle for God; Fundamentalism in Judaism, Christianity, and Islam. London: Harper Collins Publisher, 2003.

Bale, Jeffrey M. "Islamism and Totalitarianism." Totalitarian Movements and Political Religions, Vol. 10, No. 2, (Juni 2009).

Berman, Sheri. "Islamism, Revolution and Civil Society." Journal of American Political Science Association, Vol. 1 No. 2, (Juny 2003).

Bubalo, Anthony and Fealy, Greg. Zealous Democrats: Islamism and Democracy in Egypt, Indonesia, and Tukey. Sydney: ANU Press, 2008.

El Fadl, Khaled Abou. "Peaceful Jihad," in Wolfe, Michael (ed.). Taking Back Islam: American Muslims Reclaim Their Faith. USA: Royale, 2004.

Fisher, Simon (ed.). Working With Conflict: Skills and Strategies for Action. London: Zed Books, 2000.

Gunning, Joroen. Hamas in Politic: Democracy, Religion, and Violence. New York: Columbia University Press, 2009.

Hannase, Mulawarman. Islamisme dan Konflik: Perspektif Teologis dan Politis Pemikiran dan Pergerakan Hamas. Jakarta: Bolabatu Jaya \& PSATT, 2015.

Hilal, Jamil. al-Tañimāt wa al-Aḥ̨āb al-Siyäsiyyah al-Filistiniyyah baina Mahām al-Dimuqrätiyyah al-Däkhiliyyah wa al-Dimuqrätiyyah alSiyāsiyyah wa al-Taharrur. Ramallah: Muwatin, 2006.

Hroub, Khaled. "Palestinian Islamism: Conflating Nasional Liberation and Socio-Political Change." Italian Journal of International Affairs, Vol. 43, Issue 4, (December 2008). 
Hroub, Khaled. Hamas, al-Fiker wa al-Mumärasah. Beirut: Muassasah al-Dirāsat al-Filistīniyah, 1999.

Itani, Mariam. Șirà' al-Sultat baina Fatah wa Hamas fi Idārat al-Sultah al-Filistiniyyah. Beirut: Markaz al-Zaitunah li al-Dirasat wa alIstisharat, 2008.

Levitt, Matthew. Hamas: Politics, Charity, and Terrorism in the service of jihad. London: Yale University Press, 2006.

Makovsky, David. "Israeli Policy and Politics in the Wake of Hamas's Victory," in Satloff, Robert (ed.). Hamas Triumphant: Implications for Security, Politics, Economy, and Strategy. Washington: the Washington Institute for Near East Policy, 2006.

Maqdsi, Muhammad. "Charter of the Islamic Resistance Movement (Hamas) of Palestine." Journal of Palestine Studies, Vol. 22, No. 4 (Summer, 1993).

Musallam, Adnan A. From Secularism to Jihad: Sayyid Qutb and the Foundations of Radical Islamism. London: Praeger, 2005.

Rashid, Osama Abu and Syam, Paul. "Hamas: Tashaddud 'Aqa'idi wa Murūnah Siyāsiyyah.” Silsilah Tarjamat al-Zaitunah, Vol. 47 (Januari 2010).

Sinno, Abdulkader H. and Khanani, Ahmad. "Opportunities and Organization: When do Islamist Parties Choose to Compete Electorally," in Salih, M. A. Mohamed. Interpreting Islamic Political Parties. New York: Palgrave Macmillan, 2009.

Sivan, Emmanuel. Radical Islam, Medieval Theology and Modern Politic.

New Haven: Yale University Press, 1985.

Tamimi, Azzam. Hamas Unwritten Chapter. London: C Hurst \& Co Publisher, 2006.

Wittes, Tamara Cofman, et. Al. "Islamic Parties and Democracy." Journal of Democracy, Vol. 19, (July 2008).

Zanotti, Jim, et. al. "Israel and Hamas: Conflict in Gaza (20082009)" in Nejc Kardelj (ed.). Israel Versus Hamas. UK: Nova Science Publication, 2010. 
Zuaib, Khalid Khalil Mahmud. al'Aläqah Baina Harakah alMuqäwamah al-Islämiyyah (Hamas) wa al-Urdun. Amman: Jami'ah Khalil, 2010.

Zweiri, Mahjoob. "The Hamas Victory: Shifting Sands or Major Earthquake?” Third World Quarterly, Vol. 27, No. 4 (2006). 